Original Research Paper

\title{
Synthesis of Well-Defined Vinyl End-Functional Polystyrene Using Multifunctional Initiator by Atom Transfer Radical Polymerization
}

\author{
${ }^{1,2}$ Samiul Islam Chowdhury, ${ }^{2}$ Roushown Ali and ${ }^{2}$ Tariqul Hasan \\ ${ }^{I}$ Department of Chemistry, Bangladesh University of Textiles, Dhaka-1208, Bangladesh \\ ${ }^{2}$ Department of Chemistry, University of Rajshahi, Rajshahi-6205, Bangladesh
}

\author{
Article history \\ Received: 17-05-2015 \\ Revised: 24-07-2015 \\ Accepted: 06-08-2015 \\ Corresponding Author: \\ Samiul Islam Chowdhury \\ Department of Chemistry \\ Bangladesh University of \\ Textiles Dhaka-1208, \\ Bangladesh \\ Email: samibutex13@yahoo.com
}

\begin{abstract}
Atom Transfer Radical Polymerization (ATRP) has proven to be a powerful technique to obtain polymers with narrow polydispersities and controlled molecular weight. It also offers control over chain-ends. $\mathrm{N}$-allyl2-bromopropinamide (ABPN) was synthesized by one step reaction which involved on amidification of 2-bromo-propionyl bromide with allyl amine. ${ }^{1} \mathrm{H}$ NMR has confirmed the structure of the ABPN. The well-defined polystyrene was synthesized by using ABPN as initiator in ATRP method. The results of the polymerization were significantly affected by reaction conditions. The vinyl end-functional polystyrene obtained was characterized by Gel Permeation Chromatography (GPC) and NMR analysis.
\end{abstract}

Keywords: Functional Initiator, Atom Transfer, Radical Polymerization, Polystyrene, Acetamide

\section{Introduction}

The development of Living Radical Polymerization (LRP) techniques constitutes one of the key developments in the field of synthetic polymer chemistry, allowing for the synthesis of a variety of polymers with molecular weight distributions and well defined architectures, with precise control over the compositions and structures (Wang and Matyjaszewski, 1995a; 1995b; Kato et al., 1995; Kotani et al., 1996; Matyjaszewski et al., 1997a). Synthesis of well defined reactive end-functional polymers has great importance for their use as macromonomer, macroinitiator, precursor for block copolymers etc. Recently a living radical polymerization method "Atom Transfer Radical Polymerization" (ATRP) has emerged as a versatile technique that has been applied broadly because of the robustness of the chemistry and the commercial availability of many initiators, catalysts and ligands (Tsarevsky et al., 2008; Kamigaito, 2011). As with other LRP techniques, control of the $\alpha$-chain terminus is accessed from the initiator design, which for ATRP most often involves an alkyl halide with an activating substituent on the $\alpha$-carbon that undergoes homolytic cleavage in the presence of catalyst to initiate polymerization. Since ester groups are good activating groups, $\alpha$-haloester-based compounds are commonly used as ATRP initiators, whereby the ester unit can also carry functionality. The functionality incorporated into the polymer via an ester linkage is prone to hydrolysis; however, this lability has been overcome by their replacement with amide linkages through the use of $\alpha$ halo amide-based initiators (Patten et al., 1996; Matyjaszewski et al., 1997b). The presence of amides are often considered to present unique challenges for ATRP in the production of polymers with narrow molecular weight distribution and having molecular weights in agreement with theoretical values. A recent report from Haddleton's laboratory thoroughly examined the conditions under which amide containing ATRP initiators gave well-controlled polymerization of various methacrylates and styrene (Matyjaszewski et al., 1997b). Prior work in Sawamoto's laboratory demonstrated the preparation of poly (methyl methacrylate) with narrow Polydispersity Index (PDI) using $N, N$-dimethyl-2bromopropanamide as the initiator (Patten et al., 1996). Matyjaszewski's laboratory has studied the polymerization of methacrylamides using a model $\alpha$-haloamide-based initiators, obtaining well defined block copolymers (Coca et al., 1998). Recently, scientists (Xia et al., 2005) have employed various chloro-propionamides as initiators to polymerize $\mathrm{N}$-isopropylacrylamide with narrow molecular weight distribution to study the influence of the end group composition resulting from the initiators on the thermal properties (Percec et al., 1997). Well-defined end functional polymers are useful as building blocks for design and synthesis of various complex macromolecular architectures such as block (Guillerm et al., 2012; 
Wang et al., 2013; Glaied et al., 2014), graft (Zhang et al., 2012; Lav et al., 2013), star (Cai et al., 2012; Ratkanthwar et al., 2013) copolymers etc. which find applications in biomedical (Bauer et al., 2013), tissue engineering (Martina and Hutmacher, 2007), materials (Singh et al., 2012) and surface sciences (Lee et al., 2007). Although various end-functional polymers are reported so far, the synthesis of amide group containing reactive end-functional polymers still have an interest due to it's protein coupling ability to polymer and biomedical applications (Boyer et al., 2011). Therefore, in this study amide group containing vinyl endfunctional ABPN was synthesized and the ATRP of styrene was investigated using ABPN as initiator. The initiator efficiency and polymer properties also studied.

\section{Materials and Methods}

\section{Materials}

2-bromo-propionylbromide was purchased from Sigma Aldrich and used without further purification. Triethyl amine was purified by distillation followed by stirring with $\mathrm{CaH}_{2}$ for $24 \mathrm{~h}$. Allyl amine and bipyridine (BiPy) were purchased from Fluka. Styrene (St) was purchased from Aldrich and it was purified by passing through an alumina column to remove stabilizer and then stirred with $\mathrm{CaH}_{2}$ for $8 \mathrm{~h}$ and filtered. Copper (I) bromide (98\%, Aldrich) was purified according to a published procedure (Miller and Matyjaszewski, 1999). Tetrahydrofurane (THF), methanol and other common solvents were from Sigma Aldrich and purified by distillation.

\section{Analytical Procedures}

Molecular weight $\left(M_{\mathrm{n}}\right)$ and molecular weight distribution $\left(M_{\mathrm{w}} / M_{\mathrm{n}}\right)$ of polymer were measured by Toyo soda HLC-802; Column, GMH6 ×2+G4000H8; eluent, $\mathrm{CHCl}_{3}$ as solvent and calibrated by polystyrene standards. ${ }^{1} \mathrm{H}$ NMR spectra of ABPN and polymers were recorded at room temperature on a JEOL GX 500 spectrometer operated at $400 \mathrm{MHz}$ in pulse Fourier transform mode with chloroform- $d$ as solvent. The peak of chloroform in chloroform- $d$ (7.26 ppm for ${ }^{1} \mathrm{H}$ ) was used as internal reference.

\section{Methods}

\section{Synthesis of $A B P N$}

Allyl amine (1) (2.26 mL, $30 \mathrm{mmol})$ and triethylamine (6.0 mL, $43 \mathrm{mmol}$ ) were dissolved in $40 \mathrm{~mL}$ of THF. The solution was cooled in an ice-water bath. To this solution, $3.2 \mathrm{~mL}$ (30 mmol) of 2-bromopropinyl bromide (2) in 20 $\mathrm{mL}$ of THF was added drop-wise. The mixture was stirred for $2 \mathrm{~h}$ at room temperature (1 reacted with 2 to yield $\mathrm{ABPN}$ and $\mathrm{HBr} ; \mathrm{HBr}$ was absorbed by triethylamine). Triethylamine hydrogen bromide salt was filtered out. THF in the filtrate was removed under vacuum at room temperature. The residual was dissolved in diethyl ether and washed with $50 \mathrm{~mL}$ of water three times. The aqueous part were combined and shaken with $50 \mathrm{~mL}$ of fresh diethyl ether. The total ether solution was then dried over anhydrous sodium sulphate for overnight. After filtering off the drying agent, ether was distilled out under vacuum. A yellowish liquid was obtained. A further distillation under high vacuum gave a light yellowish liquid; yield $1.8 \mathrm{~mL},(69 \%)$. The structure of the product was characterized by NMR analysis.

${ }^{1} \mathrm{H}$ NMR $\left(\mathrm{CDCl}_{3}\right): 6.9 \mathrm{ppm}(\mathrm{s}, 1 \mathrm{H},-\mathrm{NH}) ; 5.6 \mathrm{ppm}$ (m, $\left.1 \mathrm{H}, \mathrm{CH}_{2}=\mathrm{CH}-\right) ; 5.1 \mathrm{ppm}\left(\mathrm{dd}, 2 \mathrm{H}, \mathrm{CH}_{2}=\mathrm{CH}-\right) ; 4.4$ ppm (q, $\left.1 \mathrm{H},-\mathrm{BrCH}-\mathrm{CH}_{3}\right) ; 3.8$ ppm (d, $2 \mathrm{H}, \mathrm{CH}-\mathrm{CH}_{2}-\mathrm{NH}-$ ); $1.7 \mathrm{ppm}\left(\mathrm{d}, 3 \mathrm{H},-\mathrm{CH}-\mathrm{CH}_{3}\right)$.

\section{Polymerization}

Polymerization was carried out in a $50 \mathrm{~mL}$ Schelnk type reactor equipped with magnetic stirrer in nitrogen atmosphere. The reactor was charged with prescribed amount of CuBr-bipyridine and a tiny magnetic capsule. Three cycles of vacuum-evacuation of reactor and fill-up with nitrogen gas were performed and the reactor was then sealed with rubber septum. A required amount of degassed styrene and ABPN were added with a syringe. The reactor was placed in an oil bath at the desired temperature controlled by a thermostat and the reaction mixture was stirred for certain time. At timed intervals, the polymerizations were stopped by addition of methanol followed by cooling the reactor into ice-water and the polymer was precipitated in methanol by stirring over night. The polymers obtained were filtered, adequately washed with methanol and dried under vacuum at $60^{\circ} \mathrm{C}$ for $6 \mathrm{~h}$.

\section{Results}

The initiator N-allyl-2-bromopropinamide (ABPN) was synthesized from the reaction between allyl amine and 2-bromopropionyl bromide in the presence of triethylamine (Scheme 1) according to the procedure described in experimental section.

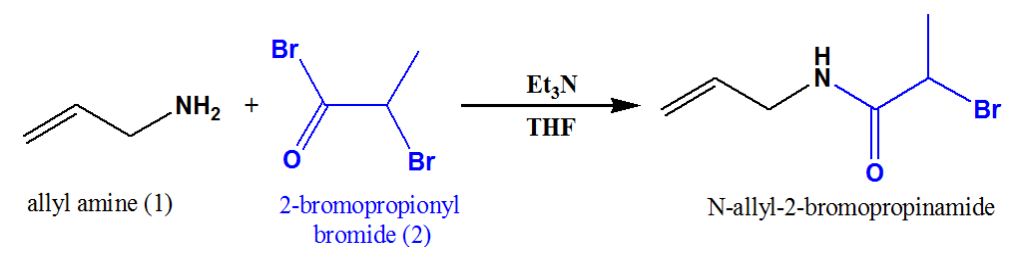

Scheme 1. Synthesis of N-allyl-2-bromopropinamide (ABPN) 
Table 1. Effect of the temperature on polymerization of styrene with $\mathrm{CuBr} / \mathrm{BiPy} / \mathrm{ABPN}$

\begin{tabular}{|c|c|c|c|c|c|c|}
\hline Entry & $\begin{array}{l}\text { St/ABPN } \\
(\mathrm{mmol})\end{array}$ & $\begin{array}{l}\text { Temperature } \\
\left({ }^{\circ} \mathrm{C}\right)\end{array}$ & $\begin{array}{l}\text { Yield } \\
(\mathrm{g})\end{array}$ & $M_{\mathrm{n}} \times 10^{3}$ & $M_{\mathrm{w}} \times 10^{3}$ & $M_{\mathrm{w}} / M_{\mathrm{n}}$ \\
\hline 1 & 500 & 75 & trace & - & - & - \\
\hline 2 & 500 & 100 & 0.2274 & 10.565 & 14.451 & 1.36 \\
\hline 3 & 500 & 115 & 1.4286 & 28.494 & 33.820 & 1.20 \\
\hline
\end{tabular}

Polymerization conditions: $[\mathrm{CuBr}=0.054 \mathrm{mmol}$, Bipy $=0.108 \mathrm{mmol}$, Styrene $=3.1 \mathrm{~mL}(27 \mathrm{mmol})$, Time $=8 \mathrm{~h}]$

Table 2. Effect of the ratio of styrene(St)/ABPN on polymerization of styrene

\begin{tabular}{|c|c|c|c|c|c|c|}
\hline Entry & $\begin{array}{l}\text { St/ABPN } \\
(\mathrm{mmol})\end{array}$ & $\begin{array}{l}\text { Temperature } \\
\left({ }^{\circ} \mathrm{C}\right)\end{array}$ & $\begin{array}{l}\text { Yield } \\
(\mathrm{g})\end{array}$ & $M_{\mathrm{n}} \times 10^{3}$ & $M_{\mathrm{w}} \times 10^{3}$ & $M_{\mathrm{w}} / M$ \\
\hline 4 & 250 & 115 & 0.9926 & 11.735 & 14.167 & 1.18 \\
\hline 5 & 500 & 115 & 1.4286 & 28.494 & 33.820 & 1.20 \\
\hline 6 & 1000 & 115 & 1.8066 & 41.903 & 55.414 & 1.32 \\
\hline
\end{tabular}

Polymerization conditions: $[\mathrm{CuBr}=0.054 \mathrm{mmol}$, Bipy $=0.108 \mathrm{mmol}$, Styrene $=3.1 \mathrm{~mL}(27 \mathrm{mmol})$, Time $=8 \mathrm{~h}]$

Table 3. Effect of time on polymerization of styrene with $\mathrm{CuBr}$ /Bipyridine/ABPN

\begin{tabular}{lllllll}
\hline Entry & Initiator & $\begin{array}{l}\text { Time } \\
\text { (hours) }\end{array}$ & $\begin{array}{l}\text { Yield } \\
(\mathrm{g})\end{array}$ & $M_{n} \times 10^{3}$ & $M_{w} \times 10^{3}$ & $M_{\mathrm{w}} / \mathrm{M}_{\mathrm{n}}$ \\
\hline 7 & ABPN & 6 & 0.725 & 14.878 & 18.908 & 1.27 \\
8 & “ & 8 & 1.429 & 28.494 & 33.820 & 1.20 \\
9 & “ & 9 & 2.068 & 41.382 & 49.938 & 1.20 \\
\hline
\end{tabular}

Polymerization conditions: $\mathrm{CuBr}=0.054 \mathrm{mmol}$, Bipy $=0.108, \mathrm{mmol}$, Styrene $=3.1 \mathrm{~mL}$, Temperature $=115^{\circ} \mathrm{C}$

The polymerization of styrene was carried out by ATRP using ABPN in conjunction with cupper (I) bromide and bipyridine as a catalyst under nitrogen atmosphere at different temperature $\left(70,100\right.$ and $\left.115^{\circ} \mathrm{C}\right)$ to investigate the catalytic efficiency at a suitable conditions. The polymerization results obtained at various temperatures were displayed at Table 1.

Styrene was then polymerized by ATRP at $115^{\circ} \mathrm{C}$ initiated with $\mathrm{ABPN}$ at different styrene/initiator ratio using same catalyst system under nitrogen atmosphere. The effect of styrene/initiator ratio in the polymerization was summarized in Table 2.

The dependence of polymer yield and molecular weight $\left(M_{n}\right)$ on polymerization time was investigated by batch method to check the living nature of this catalyst system at $115^{\circ} \mathrm{C}$. The yield of the polymer, molecular weight and molecular weight distribution of the polymers obtained by different polymerization time were summarized in Table 3.

\section{Discussion}

The initiator ABPN was characterized by ${ }^{1} \mathrm{H}$ NMR. In the ${ }^{1} \mathrm{H}$ NMR spectrum of the ABPN (Fig. 1), several additional signals were appeared including the signals of 2-bromopropionyl bromide and the additional signals were clearly assigned as follows. A singlet at $6.9 \mathrm{ppm}$ was appeared for assumable to $-\mathrm{NH}-$ proton. A mutiplate at $5.6 \mathrm{ppm}$ and a double doublet at $5.1 \mathrm{ppm}$ assignable to $-\mathrm{CH}=\mathrm{CH}_{2}$ and $-\mathrm{CH}=\mathrm{CH}_{2}$ protons, respectively, indicates the presence of vinyl group. The splitting (double doublet) of the vinyl $\left(\mathrm{CH}_{2}=\right)$ protons indicates the presence of cis-trans isomers of
ABPN. A doublet appeared at $3.8 \mathrm{ppm}$ was assigned to $=\mathrm{CH}-\mathrm{CH}_{2}-\mathrm{NH}-$ proton.

The results of the polymerization styrene using ABPN as initiator in conjunction with cupper (I) bromide and bipyridine at different temperature (Table 1) showed that a trace amount of the polymer was obtained at $75^{\circ} \mathrm{C}$ whereas the yield of polymer was increased with raising the polymerization temperature at 100 and $115^{\circ} \mathrm{C}$. The highest yield and $M_{n}$ of the polymer were obtained at $115^{\circ} \mathrm{C}$. The GPC curves of the polymer obtained at $115^{\circ} \mathrm{C}$ was shifted to the higher molecular weight region compared to the GPC curve of the polymer obtained at $100^{\circ} \mathrm{C}$ (Fig. 2). The molecular weight distribution $\left(M_{w} / M_{n}\right)$ of the polymer became narrow with increasing polymerization temperature. These results suggest that both the initiation and propagation rate of the styrene polymerization in the presence of ABPN initiator were increased at high temperature.

The polymerization of styrene was then carried out by ATRP initiated with ABPN in the presence of cupper (I) bromide and bipyridine at different styrene/initiator ratio at $115^{\circ} \mathrm{C}$ under nitrogen atmosphere. The ratio of styrene and ABPN (St/ABPN) significantly affect on the polymerization of styrene (Table 2). The yield of polymers was increased with increasing the ratio of styrene and ABPN. The polymers obtained with high molecular weight $\left(M_{n}\right)$ and narrow molecular weight distribution $\left(M_{w} / M_{n} \sim 1.18\right)$. The $M_{n}$ value of the polymers was increased with the increasing St/ABPN ratio. The GPC curves of the polymers obtained from the feed ration $\mathrm{St} / \mathrm{ABPN}=1000, \mathrm{St} / \mathrm{ABPN}=500$ and $\mathrm{St} / \mathrm{ABPN}=250$ are displayed in Fig. 3. 


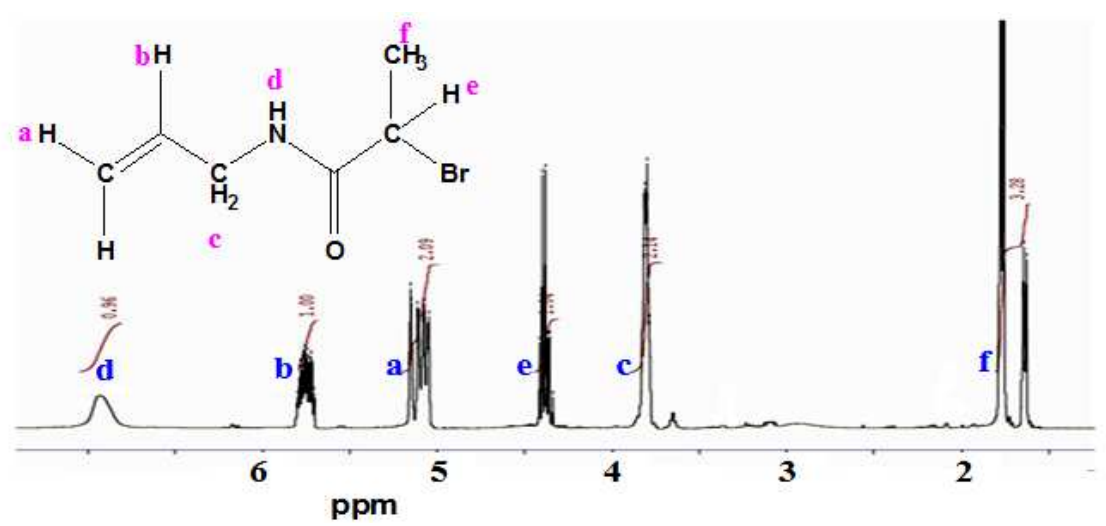

Fig. 1. ${ }^{1} \mathrm{H}$ NMR spectrum of initiator ABPN

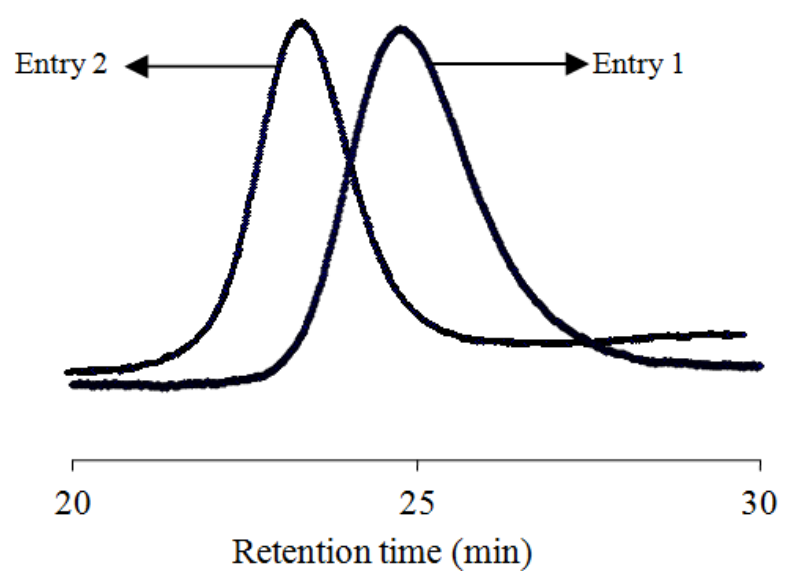

Fig. 2. GPC curves polymer obtained using ABPN

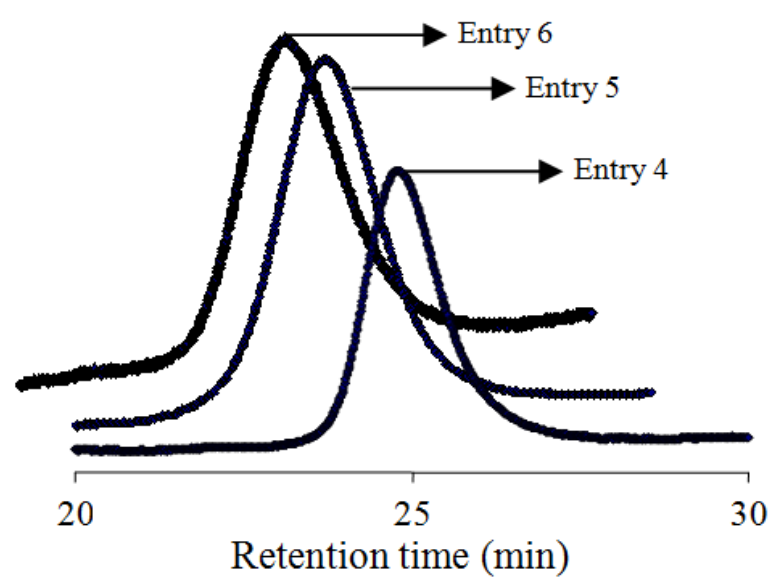

Fig. 3. GPC curves polymer obtained using ABPN

The GPC curve of the polymer obtained from the higher monomer concentration $(\mathrm{St} / \mathrm{ABPN}=1000)$ was shifted to the higher molecular weight region than that of the polymer obtained from lower monomer concentration $(\mathrm{St} / \mathrm{ABPN}=500)$. The $M_{n}$ value $\left(41.9 \times 10^{3}\right)$ of the polymer obtained from the feed ratio of $\mathrm{St} / \mathrm{ABPN}=1000$ was higher than the $M_{n}$ value $\left(28.5 \times 10^{3}\right)$ of the polymer obtained from the feed ratio of St/ABPN $=500$.

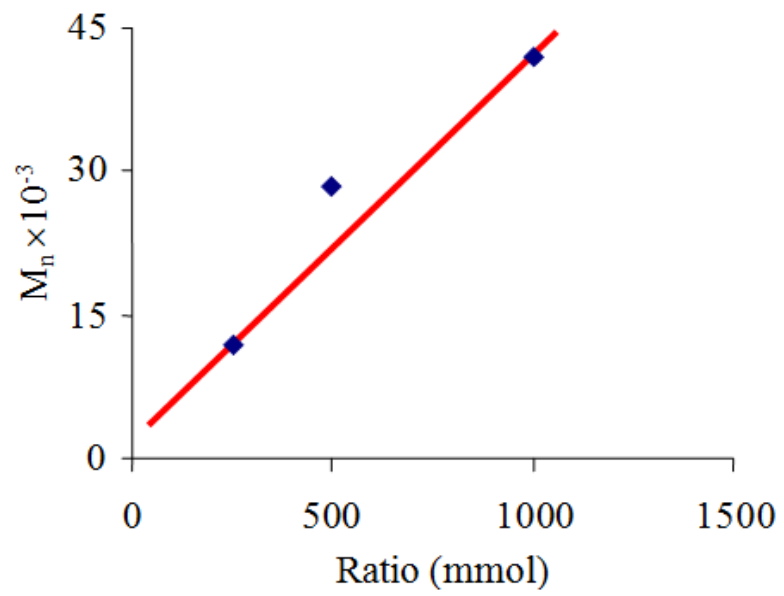

Fig. 4. Ratio (monomer/initiator) versus $M_{n}$

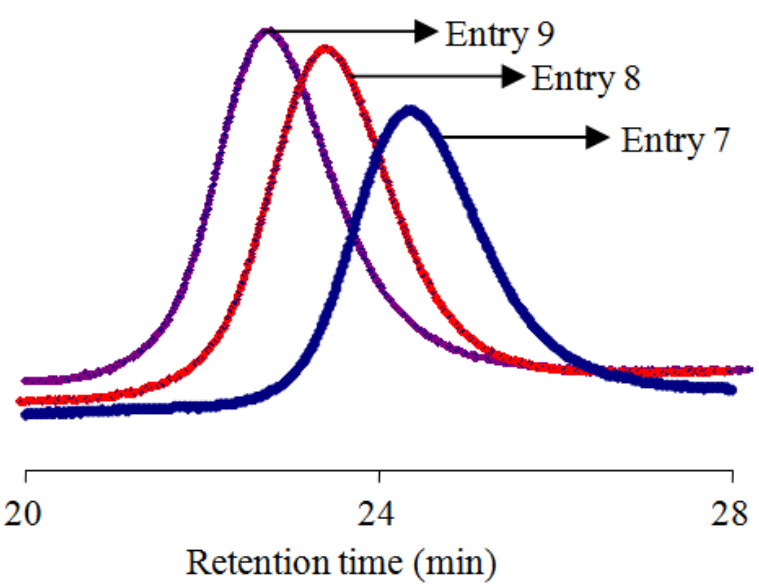

Fig. 5. GPC curves polymer obtained using ABPN

These results suggest that the higher propagation rate occurred at higher monomer concentration in feed. The linear relationship of molecular weight of the polymers with St/ABPN ratio (Fig. 4) also supported the above results. 


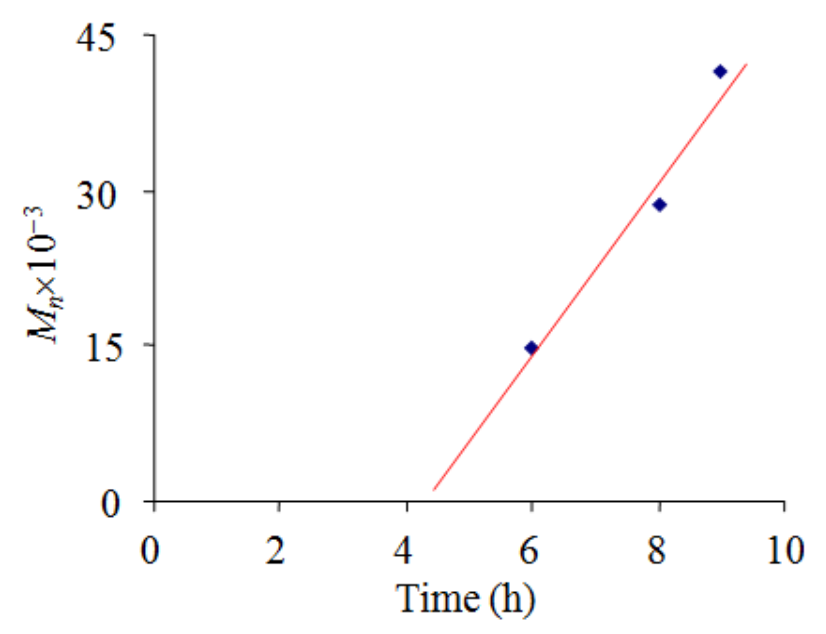

Fig. 6. Plot of Mn versus polymerization time

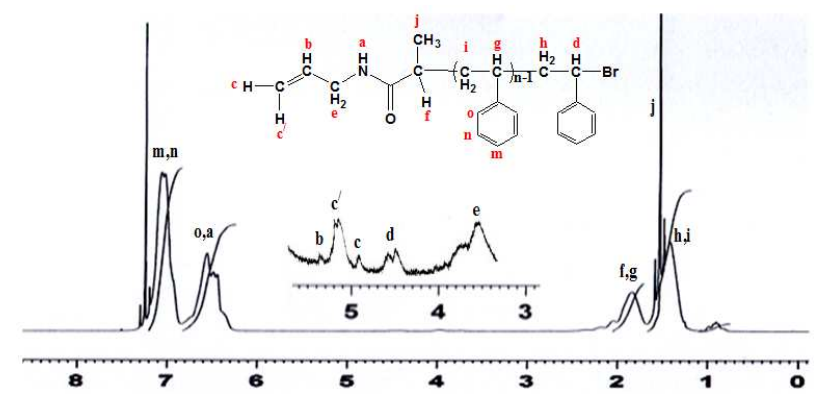

Fig. 7. ${ }^{1} \mathrm{H}$ NMR spectrum of vinyl end-functional polystyrene

To produce polymer with narrow polydispersity is one of the main criteria for a living polymerization system. The initiator ABPN combined with $\mathrm{CuBr} /$ bipyridene catalyst system gave the polymers with narrow polydispersity $\left(M_{w} / M_{n}=1.20\right.$ at $115^{\circ} \mathrm{C}$ (Table 2, entry 5 ). This result therefore promoted us to make sure the living nature of ABPN $/ \mathrm{CuBr} /$ bipyridene catalyst system at $115^{\circ} \mathrm{C}$. Thus, the dependence of polymer yield and $M_{n}$ on polymerization time was investigated by batch method to check the living nature of this catalyst system. The molecular weight and molecular weight distribution of the polymers obtained by different polymerization time were summarized in Table 3.

The GPC curves of polymers obtained from different period of time (6, 8 and 9 h) were compared in Fig. 5.

The GPC curves were shifted to the higher molecular weight region with increasing polymerization time and keeping narrow $M_{w} / M_{n}$. The plot of time Vs $M_{n}$ showed linear relationship with a slop at initial period in Fig. 6. The yield also increased with time and showed linear relationship. These results suggest that the living polymerization of styrene proceeded at $115^{\circ} \mathrm{C}$ by $\mathrm{ABPN} / \mathrm{CuBr} / \mathrm{BiPy}$ catalyst system with slow initiation.
The structure of polystyrene obtained with ABPN/CuBr/Bipyridine catalyst system was investigated by the ${ }^{1} \mathrm{H}$ NMR analysis. The ${ }^{1} \mathrm{H}$ NMR spectrum of polystyrene obtained was displayed in Fig. 7 and the signals appeared were assigned by compare with the ${ }^{1} \mathrm{H}$ NMR spectrum of ABPN.

In the ${ }^{1} \mathrm{H}$ NMR spectrum of polystyrene, the presence of a double doublet at 5.4 and $4.9 \mathrm{ppm}$ assignable to vinyl protons and a signal at $4.5 \mathrm{ppm}$ assignable to $\mathrm{CH}$ proton $\alpha$ - to $\mathrm{Br}$ indicated that the polymerization was initiated with ABPN. A broad signal at $7.1 \mathrm{ppm}$ was assigned to aromatic protons (meta- and para-position) of styrene unit and at 6.5 ppm for ortho-proton. The signals observed at 1.37 and $1.79 \mathrm{ppm}$ were assigned for the $\mathrm{CH}_{2}$ and $\mathrm{CH}$ protons of main chain of polystyrene, respectively.

\section{Conclusion}

The initiator ABPN was synthesized in a good yield. The structure of initiator ABPN was characterized by ${ }^{1} \mathrm{H}$ NMR analysis. The initiator was successfully applied for $\mathrm{Cu}(\mathrm{I})$-bipyridine mediated ATRP polymerization of styrene. The polymerization of styrene with $\mathrm{ABPN} / \mathrm{CuBr} / \mathrm{BiPy}(1: 1: 2)$ was investigated at various conditions. The yield and molecular weight of polymers were increased linearly with increasing styrene-ABPN ratio, time and temperature. In time dependence polymerization, the $M_{n}$ values of the polymer linearly increased against time after a certain period keeping narrow molecular weight distribution $\left(M_{w} / M_{n}=1.14\right)$. These results suggest that the living polymerization of styrene proceeded at $115^{\circ} \mathrm{C}$ by ABPN/CuBr/BiPy catalyst system with slow initiation. The presence of amido-functional vinyl end group in the polymer chain was confirmed by ${ }^{1} \mathrm{H}$ NMR analysis.

\section{Acknowledgement}

We especially grateful to Dr. Jun-ichi Mamiya, Assistant Professor, Chemical Resources Laboratory, Tokyo Institute of Technology, Japan for GPC analysis of polymer samples and we also would like to thank to Analytical Research division, Bangladesh Council for Scientific and Industrial Research (BCSIR), Dhaka, Bangladesh for NMR analysis.

\section{Funding Information}

This work was supported by the Ministry of Science and Technology, Government of the People's Republic of Bangladesh; a Capacity Utilization Programme under Special Allocation for Science and Technology.

\section{Author's Contributions}

Samiul Islam Chowdhury: All experimental works of this research were done by Mr. Chowdhury. 
Roushown Ali: Interpretation of NMR spectra and GPC data were done Dr. Ali.

Tariqul Hasan: This research was carried out in Hasan's laboratory. Over all supervision of experimental works, data analyses were done by Professor Hasan.

\section{Ethics}

The amide group containing vinyl end-functional polystyrene obtained from the work is a reactive macromonomer, which could be used as a precursor for tailored copolymers and also in biomedical applications.

\section{References}

Bauer, M., S. Schroeder, L. Tauhardt, K. Kempe and U.S. Schubert et al., 2013. In vitro hemocompatibility and cytotoxicity study of poly(2methyl-2-oxazoline) for biomedical applications. J. Polymer Sci. A Polymer Chem., 51: 1816-1821. DOI: $10.1002 /$ pola.26564

Boyer, C., X. Huang, M.R. Whittaker, V. Bulmus and T.P. Davis, 2011. An overview of protein-polymer particles. Soft Matter, 7: 1599-1614.

DOI: $10.1039 /$ C0SM00412J

Cai, T., M. Li, K.G. Neoh and E.T. Kang, 2012. Preparation of stimuli responsive polycaprolactone membranes of controllable porous morphology via combined atom transfer radical polymerization, ring-opening polymerization and thiol-yne click chemistry. J. Mater. Chem., 22: 16248-16258. DOI: 10.1039/C2JM33419D

Coca, S., C.B. Jasieczek, K.L. Beers and K. Matyjaszewski, 1998. Polymerization of acrylates by atom transfer radical polymerization. Homopolymerization of 2-hydroxyethyl acrylate. J. Polym. Sci. Part A Polym. Chem., 36: 1417-1424. DOI:10.1002/(SICI)10990518(19980715)36:9<1417 ::AID-POLA9>3.0.CO;2-P

Glaied, O., C. Delaite and S. Bistac, 2014. Crystalline properties of poly( $\varepsilon$-caprolactone)-blockpoly(vinyl acetate) block copolymers: Influence of synthesis route. Polymer Int., 63: 703-708.

DOI: $10.1002 /$ pi.4575

Guillerm, B., S. Monge, V. Lapinte and J.J. Robin, 2012. Well-defined poly(oxazoline)-b-poly(acrylate) amphiphilic copolymers: From synthesis by polymerpolymer coupling to self-organization in water. J. Polym Sci. A Polymer Chem., 51: 1118-1128. DOI: $10.1002 /$ pola.26474

Kamigaito, M., 2011. Recent developments in metalcatalyzed living radical polymerization. Polymer J., 43: 105-120. DOI: $10.1038 /$ pj.2010.113
Kato, M., M. Kamigaito, M. Sawamoto and T. Higashimura, 1995. Polymerization of methyl methacrylate with the carbon tetrachloride/dichlorotris-

(triphenylphosphine)ruthenium(II)/methylaluminum Bis(2,6-di-tert-butylphenoxide) initiating system: Possibility of living radical polymerization. Macromolecules, 28: 1721-1723.

DOI: $10.1021 / \mathrm{ma} 00109 \mathrm{a} 056$

Kotani, Y., M. Kato, M. Kamigaito and M. Sawamoto, 1996. Living radical polymerization of alkyl methacrylates with ruthenium complex and synthesis of their block copolymers. Macromolecules, 29: 6979-6982.

DOI: $10.1021 / \mathrm{ma} 960418 \mathrm{a}$

Lav, T.X., P. Lemechko, E. Renard, C. Amiel and V. Langlois et al., 2013. Development of a new azidooxazoline monomer for the preparation of amphiphilic graft copolymers by combination of cationic ring-opening polymerization and click chemistry. React. Funct. Polymer, 73: 1001-1008. DOI: 10.1016/j.reactfunctpolym.2013.04.013

Lee, J.H., Y.C. An, D.S. Choi, M.J. Lee and K.M. Kim et al., 2007. Fabrication of a nano-porous polyoxazoline-coated tip for scanning probe nanolithography. Macromol. Symp., 249-250: 307-311. DOI: 10.1002/masy.200750350

Martina, M. and D.W. Hutmacher, 2007. Biodegradable polymers applied in tissue engineering research: A review. Polymer Int., 56: 145-157.

Matyjaszewski, K., S. Jo, H.J. Paik and S.G. Gaynor, 1997b. Synthesis of well-defined polyacrylonitrile by atom transfer radical polymerization. Macromolecules, 30: 6398-6400. DOI: $10.1021 / \mathrm{ma} 9706384$

Matyjaszewski, K., T.E. Patten and J. Xia, 1997a. Controlled/“living" radical polymerization. kinetics of the homogeneous atom transfer radical polymerization of styrene. J. Am. Chem. Soc., 119: 674-680. DOI: 10.1021/ja963361g

Miller, P.J. and K. Matyjaszewski, 1999. Atom transfer radical polymerization of (meth)acrylates from poly(dimethylsiloxane) macroinitiators. Macromolecules, 32: 8760-8767.

DOI: $10.1021 / \mathrm{ma} 991077 \mathrm{e}$

Patten, T.E., J. Xia, T. Abernathy and K. Matyjaszewski, 1996. Polymers with very low polydispersities from atom transfer radical polymerization. Science, 272: 866-868. DOI: $10.1126 /$ science.272.5263.866

Percec, V., H.J. Kim and B. Barboiu, 1997. Disulfonyl chlorides: A universal class of initiators for metalcatalyzed "living" diradical polymerization of styrene(s), methacrylates and acrylates. Macromolecules, 30: 6702-6705.

DOI: $10.1021 / \mathrm{ma} 9708508$ 
Ratkanthwar, K., N. Hadjichristidis and Z. Pudukulathan, 2013. Synthesis and characterization of well-defined regular star polyisoprenes with 3, 4, 6 and 8 arms. Chem. J., 03: 90-96.

Singh, P., A. Srivastava and R. Kumar, 2012. Synthesis of amphiphilic poly(N-vinylcaprolactam) using ATRP protocol and antibacterial study of its silver nanocomposite. J. Polymer Sci. A Polymer Chem., 50: 1503-1514. DOI: 10.1002/pola.25911

Tsarevsky, N.V., P. McCarthy, W. Jakubowski, J. Spanswick and K. Matyjaszewski, 2008. Atom Transfer Radical Polymerization (ATRP) as a tool for the synthesis of well-defined functional polymeric materials. Nanotech.

Wang, H., J. He, M. Zhang, Y. Tao and F. Li et al., 2013. Biocompatible and acid-cleavable poly $(\varepsilon-$ caprolactone)-acetal-poly(ethylene glycol)-acetalpoly( $\varepsilon$-caprolactone) triblock copolymers: Synthesis, characterization and $\mathrm{pH}$-triggered doxorubicin delivery. J. Mater. Chem. B, 1: 6596-6607.

DOI: $10.1039 / \mathrm{C} 3 \mathrm{~TB} 21170 \mathrm{C}$
Wang, J.S. and K. Matyjaszewski, 1995 b. Controlled/"living" radical polymerization. Halogen atom transfer radical polymerization promoted by a $\mathrm{Cu}(\mathrm{I}) / \mathrm{Cu}(\mathrm{II})$ redox process. Macromolecules, 28: 7901-7910.

Wang, J.S. and K. Matyjaszewski, 1995a. Controlled/"living" radical polymerization. atom transfer radical polymerization in the presence of transition-metal complexes. J. Am. Chem. Soc., 117: 5614-5615. DOI: 10.1021/ja00125a035

Xia, Y., N.A.D. Burke and H.D.H. Stöver, 2006. End group effect on the thermal response of narrowdisperse poly( $N$-isopropylacrylamide) prepared by atom transfer radical polymerization. Macromolecules, 39: 2275-2283. DOI: $10.1021 / \mathrm{ma} 0519617$

Zhang, K., Y. Wang, W. Zhu, X. Li and Z. Shen, 2012. Synthesis, characterization and micellization of PCL-g-PEG copolymers by combination of ROP and "Click" chemistry via "Graft onto" method. J. Polymer Sci. A Polymer Chem., 50: 2045-2052. DOI: $10.1002 /$ pola.25979 